\title{
Green Purchase Intention: An Investigation Green Brand Knowledge and Green Perceived Value of Bioplastic Products in Bandung-Indonesia
}

\author{
Rennyta Yusiana ${ }^{1}$, Arry Widodo², Agus Maolana Hidayat ${ }^{3}$ \\ ${ }^{1}$ Faculty of Applied Science, Telkom University, Indonesia \\ 2,3 Faculty of Communication and Business, Telkom University, Indonesia
}

\begin{abstract}
Currently, there is environmental and ecosystem damage, one of which is due to the accumulation of waste residue or waste originating from industry and households. Difficult waste to decompose are plastics; they accumulate in landfills, are wasted in the sea, and threaten marine ecosystems. However, if burned will produce substances that are harmful to health. This phenomenon supports people using plastic substitutes, bioplastics. It is made from cassava and vegetable derivatives and environmentally friendly and not harmful if ingested by animals. This study aims to determine the effect of Green Brand Knowledge (GBK) and Green Perceived Value (GPV) on Green Purchase Intention (GPI) of bioplastic products in Bandung, Indonesia. This research is quantitative research with descriptive and causal data analysis. The number of samples is 100 respondents who use bioplastic products in Bandung-Indonesia. The number of consumers is unknown, so the number of samples is determined by the Bernoulli formula. Data collected from the questionnaire, processed using SPSS application and path analysis method. The results showed that the respondents' perceptions of each variable: Green Brand Knowledge (GBK), Green Perceived Value (GPV), and Green Purchase Intention (GPI) were in a good category. There is a partially significant relationship between Green Brand Knowledge (GBK) and Green Purchase Intention (GPI) and a simultaneous relationship, Green Brand Knowledge (GBK) and Green Perceived Value (GPV) with Green Purchase Intention (GPI) has a very strong and significant relationship. Focusing the dimensions of Green Brand Knowledge (GBK), Green Perceived Value (GPV), and Green Purchase Intention (GPI) to the respondent who uses bioplastic products in Bandung-Indonesia, so the memory in the minds of consumers is centered on these variables. This study provides input on relevant theories regarding the effect of Green Brand Knowledge (GBK) and Green Perceived Value (GPV) on Green Purchase Intention (GPI) of bioplastic products in Bandung-Indonesia and supports increased consumer use of environmentally friendly products. It is known that improvements in the customer dimension and environmental concern are to increase Green Perceived Value (GPV) so that consumers get overall benefits, and something is sacrificed based on environmental desires, in the hope that there will be sustainability and an increase in green needs.
\end{abstract}

Keywords: Green Brand Knowledge, Green Perceived Value, Green Purchase Intention.

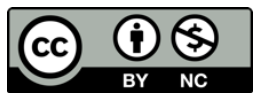

This is an open access article under the CC-BY-NC license.

\section{INTRODUCTION}

Environmental and ecosystem damage can be caused by various things, one of which is the accumulation of waste from the disposal of waste originating from industry or households. Plastic is a material that cannot be separated from human life. Because it is difficult to decompose, plastic waste tends to accumulate in landfills and can cause problems and even damage the environment. If plastic waste is burned, it can produce substances that are harmful to health. Plastic waste that is difficult to decompose and is disposed of at sea can threaten marine ecosystems, both animals and plants (lingkunganhidup.co, 2017).

In addition to causing environmental damage, which is difficult to decompose, plastic waste can threaten marine ecosystems. Of the total area of coral reefs in Indonesia, only $29.79 \%$ are still in good to very good condition, while the rest have suffered damage mostly due to humans, including plastic waste dumped into the sea. Small, non-recyclable plastic straws also play a role in destroying coral reefs and marine life (Greenes.co, 2018).

Due to a large amount of plastic waste and all the problems it causes, a country, both government and society, must be able to process plastic waste optimally so that it does not cause more severe environmental damage. One way is to make recycling from these plastic wastes. Unfortunately, not all 
plastic waste can be recycled. Plastic that can be recycled is simply the logo Fully Recyclable (FUREC) (Warta Ekonomi, 2019).

Based on this phenomenon, an alternative solution is to use environmentally friendly plastics. Bioplastics decompose in nature with the help of microorganisms for approximately 105 days (80\%) and 180 days (almost 100\%). Tests using a home composter Takakura basket, bioplastics decompose for 64 days (almost 100\%). In addition, this material is not dangerous if eaten by sea animals or animals (Cassaplast.co.id, 2020).

There are several companies in Indonesia that have produced bioplastics made from cassava, namely: Cassaplast, Avani Eco Hub, Telobag, and Greenhope. These companies have collaborated with retail, restaurants, distributions, hospitals, and so on. Bioplastic alternative use is expected to help consumers helped to reduce plastic waste.

Green brand knowledge is the level of someone's knowledge of green products. Based on research (Suki, 2016), a person's knowledge of environmentally friendly products influences consumer purchasing decisions to buy environmentally friendly products. This knowledge can be created through widely disseminating information to the public about these environmentally friendly products. Likewise, bioplastic producers disseminate information about environmentally friendly products and their impact on the environment and ecosystem. Manufacturers of bioplastic spread information through social media and actively participate in the seminar on the environment both as speakers and sponsors. Through the dissemination of this information, bioplastic producers are trying to increase public knowledge and awareness of users of green products, especially bioplastics. Shaharudin et al. (2010: 105) explained: "The values of environmentally friendly products are something that becomes customer's consideration in selecting organic products". This means that the value of the product is one of the aspects that can affect a person's purchase intention. Yang \& Peterson (2014) says that one of the requirements to make the efforts more successful in the future competition is trying to reach the goal by creating and retaining customers by providing value to consumers (perceived value).

The research that has been conducted by Kusuma (2018) regarding The Effect of Environmental Knowledge, Green Advertising, and environmental Attitude Toward Green Purchase Intention states that environmental knowledge and green advertising positively and significantly affect environmental attitude and green purchase Intention, and environmental attitude can positively and significantly affect green purchase intention. Based on such background, the following are the research objectives to be achieved; determine the influence of Green Brand Knowledge on Green Purchase Intention, determine the influence of Green Perceived Value on Green Purchase Intention, and determine the influence of Green Brand Knowledge and Green Perceived Value on Green Purchase Intention simultaneously.

\section{LITERATURE REVIEW}

Green marketing is currently the main topic of society in anticipating natural damage (Yusiana and Widodo, 2016). Zhao et al. (2014) state that green marketing is a marketing product that is assumed to be safe for the environment. There are four marketing mix (4P) in green marketing with an environmental approach, namely green product, green price, green place, and green promotion. Green products (Kumar and Ghodeswar, 2015; Tekade and Sastikar, 2015) are products that are not harmful to humans and the environment and are environmentally friendly procedures. Apart from that, the development of green products, which addresses environmental problems through product design and innovation, encourages the creation of a form of aspect that has a significant influence on today's civilization (customers, industry, and governments around the world). According to (Suki 2016; Verna et al. 2019), there are 2 types of green product classifications, that is green product design innovations and green product-offering innovations. Characteristics of green product design innovations are to reduce consumption of resources in use or manufacturing process, the replacement of hazardous substances in products, recyclable and reusable. Meanwhile, green product-offering innovations have the characteristics of non-product benefits (recovery products), emotional benefits (social, technology), logical benefits (information, health, finance). Green product characteristics (Ottman, 2011), namely, 1. The product does not contain toxic (poison) 2. Products are more durable 3. Products use raw materials from recycled materials 4 . The product uses raw materials that can be recycled 5 . The product does not use materials that can damage the environment 6 . Does not involve animal testing of products where necessary 7 . During use, do not damage the environment 8 . Using simple packaging and providing refillable products 9 . No harmful to human and animal health 10. Does not consume a lot of energy and other resources during processing, use, and sales 11. Does not produce useless waste due to packaging in a short period of time. 
According to Huang et al. (2014), Green Brand Knowledge is a green brand node in memory associated with the various associations related to environmental commitment and environmental awareness. According to Keller (1993) in Suki (2016), "Green brand knowledge provides information about a product's unique brand attributes and its benefits to the overall environment to the consumers. The two types of brand knowledge are brand awareness and brand image ". Green brand knowledge provides information about the unique brand attributes and the overall environmental benefits to consumers. The two types of brand knowledge are brand awareness and brand image. It can be concluded that Green Brand Knowledge is knowledge of the brand, whether it is the knowledge of the attribute information, uniqueness, and other things that are expected to be useful for the environment. In addition, the dramatic increase in consumer attitudes and skepticism towards eco-friendly brands shows that more consumer education strategies are associated with environmentally friendly knowledge. However, green knowledge was previously not considered in the study of green innovation. The greater the knowledge of consumers about environmental issues, the lower the uncertainty over their decision-making process, and the more they will trust and embrace green commitment brands (Chang, 2011).

The perceived importance of being environmentally friendly, as discussed previously, is a key dimension of green brand awareness. He went on to say that green brand awareness consists of brand identification and experience with an environmental perspective. This demonstrates how marketers use consumer brand awareness to influence consumer perceptions toward a brand by providing a positive brand experience.

Green Perceived Value (Chen and Chang, 2012) is an overall consumer assessment of all benefits received and what is sacrificed based on a desire for the environment, with the hope of sustainability of all green needs. According to Lin, Lobo, \& Leckie, 2017, Green perceived value is a net benefit from overall consumer assessment through product or service evaluation. Every benefit received by consumers from consuming organic products that will have a good impact on these consumers or be a benefit that can be obtained from consuming the product is a value that is felt from the product. In addition, the green perceived value appears to have a positive impact on purchases that attract interest naturally and contribute to the advancement of the relationship between customers and green brand Knowledge through the expansion of green compliance, ecological neighborly trust, autonomous brand connections, and naturally inviting dependence on a brand (Chen \& Chang, 2012; Chen., 2013; Lin, Lobo, \& Leckie, 2017). Therefore, the green perceived value award is very important when looking at the persuasive path between environmentally friendly brand information from an ecologically inviting item. In expansion, Green Brand knowledge and Information reflects the brand's capacity to supply modern settings and the success of customers 'green needs, which seems that the brand is able to meet consumers' green needs through inventive approaches such as goods and preparing for continuous progress/innovation (Chen., 2013).

Green purchase intention (Huang et al., 2014) is the desire of consumers to buy products after they realize it is green or green brand products. Green purchase intention was also measured using three items adapted from Chan Huang et al. (2014) to study the intention of Chinese consumers who engage in the purchase of environmentally friendly products, namely: a. Consider buying products because they don't pollute the environment; b. Consider switching to another brand for ecological reasons; c. Plan to switch to a version of environmentally friendly products. The conclusion of the authors is that the Green Purchase Intention is the intention of consumers to buy a product by considering the attributes possessed by these products to preserve the environment.

\section{RESEARCH METHODOLOGY}

This study uses quantitative methods that aim to compare theory with existing facts and measure the relationship between existing variables. This study uses a causal study method to determine the causal relationship between two or more variables. In this study, the causal method is used to explain the effect of Green Brand Knowledge and Green Perceived Value (independent variable) on Green Purchase Intention (dependent variable) both simultaneously and partially on Bioplastics consumers.

The scale used to measure the variables in this study is the ordinal scale, with the Likert scale instrument to obtain the proper research and correct. The ordinal scale aims to form certain categories and rank each category to indicate that there are different values in each category (Indrawati, 2015: 131). Likert scale is 
a scale used to measure attitudes, opinions, and perceptions of a person or group of people towards existing social phenomena (Sugiyono, 2017: 93).

Table 1. Operational Variables

\begin{tabular}{|c|c|c|c|}
\hline Variable & Indicators & Statement & Scale \\
\hline \multirow{2}{*}{$\begin{array}{l}\text { Green Brand } \\
\text { Knowledge }\end{array}$} & $\begin{array}{l}\text { Green Brand } \\
\text { Awareness }\end{array}$ & $\begin{array}{l}\text { 1. I know that Cassaplast is an eco- } \\
\text { friendly product brand } \\
\text { 2. The Cassaplast brand is the first } \\
\text { thing that comes to mind when it } \\
\text { comes to environmentally friendly } \\
\text { plastics }\end{array}$ & \multirow{2}{*}{ Ordinal } \\
\hline & Green Brand Images & $\begin{array}{l}\text { 3. The raw materials used to make } \\
\text { bioplastics at Cassaplast are } \\
\text { organic and do not use toxic } \\
\text { materials. } \\
\text { 4. The Cassaplast bioplastic brand is } \\
\text { an effort to reduce plastic waste. }\end{array}$ & \\
\hline \multirow{5}{*}{ Green Perceived Value } & Benefit for customer & $\begin{array}{l}\text { 5. Cassaplast bioplastic products } \\
\text { provide benefits for long term life }\end{array}$ & \multirow{5}{*}{ Ordinal } \\
\hline & Environmental benefit & $\begin{array}{l}\text { 6. Cassaplast bioplastic products can } \\
\text { meet my expectations in protecting } \\
\text { the environment. }\end{array}$ & \\
\hline & Environmental concern & $\begin{array}{l}\text { 7. Cassaplast's bioplastic products } \\
\text { are considered better because they } \\
\text { have a focus on reducing plastic } \\
\text { waste than other companies that } \\
\text { produce conventional plastics. }\end{array}$ & \\
\hline & Standard of quality & $\begin{array}{l}\text { 8. Cassaplast bioplastic products are } \\
\text { considered to have good quality } \\
\text { like conventional plastics. }\end{array}$ & \\
\hline & Price & $\begin{array}{l}\text { 9. The price of bioplastics offered is in } \\
\text { accordance with the benefits } \\
\text { provided to me and to the } \\
\text { environment. }\end{array}$ & \\
\hline \multirow{3}{*}{$\begin{array}{l}\text { Green Purchase } \\
\text { Intention }\end{array}$} & $\begin{array}{l}\text { Buying due care for the } \\
\text { environment }\end{array}$ & $\begin{array}{l}\text { 10. I intend to buy bioplastic } \\
\text { products from Cassaplast because } \\
\text { I want to contribute to reducing } \\
\text { the amount of plastic waste. }\end{array}$ & \multirow{3}{*}{ Ordinal } \\
\hline & $\begin{array}{l}\text { Buy in the future } \\
\text { because of } \\
\text { environmental } \\
\text { performance }\end{array}$ & $\begin{array}{l}\text { 11. I want to buy bioplastic } \\
\text { products from Cassaplast because } \\
\text { of the benefits to the environment }\end{array}$ & \\
\hline & $\begin{array}{l}\text { Glad to buy } \\
\text { environmentally } \\
\text { friendly products }\end{array}$ & $\begin{array}{l}\text { 12. I switched to using bioplastic } \\
\text { products at Cassaplast because } \\
\text { they are environmentally friendly. }\end{array}$ & \\
\hline
\end{tabular}

Sources: Suki (2016), Chen \& Chang (2012)

In this study, measurements were carried out through a questionnaire containing some statements, along with five possible answers that must be chosen by the respondent. The results of the answers obtained will be arranged based on the assessment criteria determined by the researcher for each statement in the questionnaire.

Data collected from the questionnaires were processed using SPSS and Path Analysis. Path analysis is a statistical analysis tool used to analyze patterns of causal relationships between variables with the aim of knowing the direct and indirect effects, either simultaneously or independently of several causal variables on an effect variable (Riduwan and Kuncoro: 2017). 


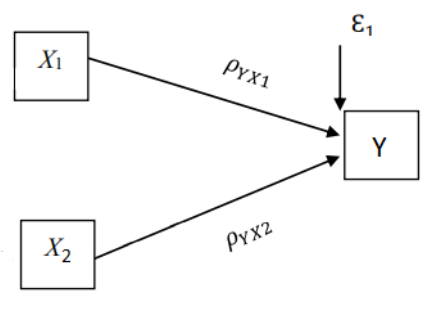

$$
Y=\rho_{Y X 1} X_{1}+\rho_{Y X 2} X_{2}+\varepsilon_{1}
$$

Information:

Figure 1. Path diagrams and Structural Equations

X1: Green Brand Knowledge

X2: Green Perceived Value

Y: Green Purchase Intention

E1: Other factors that affect Green Purchase Intention

$\rho Y X 1 X 1$ : Coefficient of Green Brand Knowledge Path on Green Purchase Intention

$\rho Y X 1 X 2$ : Coefficient of Green Perceived Value Path to Green Purchase Intention

The sampling technique is generally random to reduce the potential for human bias in the selection of cases to be included in the sample. In addition, it helps to ensure high internal validity in the measurement and to reduce the impact of potential confounding variables that occur during questionnaires and population distribution. Data collection uses research instruments and quantitative data analysis with the aim of testing predetermined hypotheses. The objects used in this research are consumers who have purchased and used bioplastic products from the Cassaplast company in Bandung, Indonesia. The distribution of the questionnaire was carried out in January - March 2020 to consumers directly.

Questionnaires were distributed to clients who had already used bioplastic products, such as the companies Deenay, Tnc7, Second Sign, Jumma Kids, Zap, Meccanism, bright, Hijup, Hijab.id, Amita House, and Rubylicious in Bandung - Indonesia. The number of consumers who use bioplastic products is unknown, so the number of samples is determined by 100 respondents using the Bernoulli formula. Furthermore, the technique used in this study uses path analysis with the Green Brand Knowledge (GBK), Green Perceived Value (GPV), and Green Product Intention (GPI) variables.

\section{RESULT AND DISCUSSION}

Based on the distribution of questionnaires to respondents, the characteristics can be seen in Table 2 as follows:

Table 2. Profile of the respondents in Bandung, $n=100$

\begin{tabular}{ccc}
$\begin{array}{c}\text { Characteristics of } \\
\text { Respondents }\end{array}$ & Information & $\mathbf{\%}$ \\
\hline Gender & Female & 53 \\
\hline Age & 25 Years $<$ & 58 \\
\hline Current Education & Bachelor & 51 \\
\hline Occupation & Employees & 53 \\
\hline Earnings/month & $5.000 .000<$ & 59
\end{tabular}

Based on the questionnaire that has been distributed, the results of the test data from the Green Brand Knowledge (GBK) variable are reliable because the Cronbach's Alpha value is $>0.60$ and the correlation level is strong, and the data can be trusted. The Cronbach's Alpha value of the Green Perceived Value (GPV) variable is reliable because the Cronbach's Alpha value is $>0.60$ and the level of correlation is strong, and the data can be trusted. Cronbach's Alpha value of the Green Product Intention (GPI) variable is reliable because Cronbach's Alpha value is $>0.60$ with a strong correlation level, data reliability can be trusted.

The data shows the results of testing the validity of Green Brand Knowledge (GBK), Green Perceived Value (GPV), and Green Product Intention (GPI) obtained correlation significant at alpha 1\%, meaning that all valid questionnaires. It is concluded that each question item from the questionnaire can be understood or accepted by respondents, in the sense that the questions on the questionnaire are able to reveal the Green Brand Knowledge (GBK), Green Perceived Value (GPV), and Green Product Intention (GPI) variables. 
Multikolinier test results for both variables between Green Brand Knowledge (GBK) and Green Perceived Value (GPV) have VIF values lower than 5, indicating the absence of a strong relationship between variables independentnya. It showed no symptoms multicolliner between two variables. Normality test results closer to normal for the data error or the residue dispersed in the direction corresponding diagonal lines and not a lot or very little was away with the straight line.

Prior to analysis, testing whether two independent variables are simultaneously associated with the Green Purchase Intention (GPI) through Anova F test or partial test by t-test as follows:

Table 3. F ANOVA ${ }^{\mathrm{b}}$

\begin{tabular}{ccccc} 
Model & Sum of Squares & df & $\begin{array}{c}\text { Mean } \\
\text { Square }\end{array}$ & F \\
\hline Regression & 405.081 & 2 & 92.712 & 92.712 \\
\hline Residual & 211.909 & 97 & 2.185 & \\
\hline Total & 616.990 & 99 & & \\
\hline
\end{tabular}

a. Dependent Variable: GPI

b. Predictors: (Constant), GPV, GBK

Source: Data Processing

ANOVA test results obtained an $\mathrm{F}$ value of $92.712, \mathrm{~F}$ table can be viewed by using the $\mathrm{F}$ table with residual degrees of freedom (df) of 97 as the denominator, and the regression $\mathrm{df}$ is 3.94 . Because $\mathrm{F}$ count $(92,712)>$ $\mathrm{F}$ table (2; $\mathrm{n}-\mathrm{k}-1)$ then $\mathrm{H} 1$ is accepted. Based on the significance in the sig column, which is 0.000 , it means that the probability of $0.000<0.05$, then $\mathrm{HO}$ is rejected and $\mathrm{H} 1$ is accepted. Then the multiple linear regression model or the variable relationship model (fit model) can be applied to analyze these variables. In other words, both variables, Green Brand Knowledge (GPK) and Green Perceived Value (GPV), have a significant relationship to Green Purchase Intention (GPI).

Table 4. Simultaneous Correlation in Path Analysis Model Summaryb

\begin{tabular}{ccccc} 
Model & $\mathrm{R}$ & $\begin{array}{c}\mathrm{R} \\
\text { Square }\end{array}$ & $\begin{array}{c}\text { Adjusted R } \\
\text { Square }\end{array}$ & $\begin{array}{c}\text { Durbin- } \\
\text { Watson }\end{array}$ \\
\hline 1 & $.820^{\mathrm{a}}$ & .657 & .649 & 2.3319 \\
\hline
\end{tabular}

a. Predictors: (Constant), GVP, GBK

b. Dependent Variable: GPI

Source: Data Processing

The relationship between Green Brand Knowledge (GBK) and Green Perceived Value (GPV) simultaneously has a significant relationship with Green Purchase Intention (GPI), where the R coefficient value of 0.810 is included in the very strong relationship category. The amount of $\mathrm{R}$ square shows the number 0.657. The coefficient of determination is used to calculate the influence of the independent variables on the dependent variable. The magnitude of the $\mathrm{R}$ square value is between 0 and 1 , which means that the greater the $\mathrm{R}$ square value, the stronger the relationship between the two variables. Conversely, the smaller the R square value, the weaker the relationship between the two variables. Thus, the simultaneous relationship between Green Brand Knowledge (GPK) and Green Perceived Value (GPV) variables can affect changes in Green Purchase intention (GPI) by $65.7 \%$, and the remaining $34.3 \%$ is influenced by other factors.

Table 5. Path coefficient Coefficientsa

\begin{tabular}{|c|c|c|c|c|c|c|}
\hline \multirow[t]{2}{*}{ Model } & \multicolumn{2}{|c|}{$\begin{array}{l}\text { Unstandardized } \\
\text { Coefficients }\end{array}$} & \multirow{2}{*}{$\begin{array}{c}\begin{array}{c}\text { Standardized } \\
\text { Coefficients }\end{array} \\
\text { Beta }\end{array}$} & \multirow[t]{2}{*}{$\mathrm{t}$} & \multicolumn{2}{|c|}{ Collinearity Statistics } \\
\hline & B & Std.Error & & & Tolerance & VIF \\
\hline $\begin{array}{c}1 \\
\text { (Constant) }\end{array}$ & 4.230 & 1.316 & & 3.215 & & \\
\hline GBK & .147 & .039 & .326 & 3.744 & .467 & 2.143 \\
\hline GPB & .318 & .051 & .541 & 6.209 & .467 & 2.143 \\
\hline
\end{tabular}

Source: Data Processing 
The calculation results in Table 6 show that the path coefficient shows the relationship between Green Brand Knowledge (GBK) and Green Perceived Value (GPV) on Green Purchase Intention (GPI), which can be described as follows:

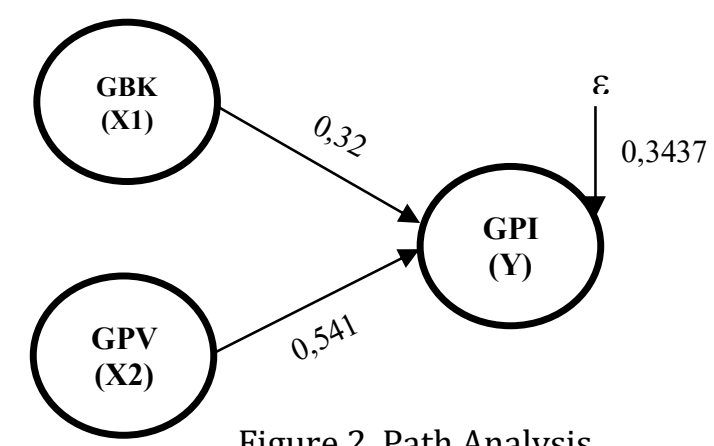

Figure 2. Path Analysis

The model above is a path analysis model which can be expressed by the following mathematical equation: $\mathrm{Y}=0,326 \mathrm{X} 1+0,541 \mathrm{X} 2$

$(\mathrm{t}=3,744) \quad(\mathrm{t}=6,209)$

Sig $0,000 \quad$ Sig 0,000

$\mathrm{R}=0,810 \quad \mathrm{R}$ Square $=0,657$

$\mathrm{F}=92,172 \quad$ Sig 0,000

The results of the coefficients in the table and figure above show the path coefficient value (X1 to Y) of 0.326 and the regression coefficient (X2 to $\mathrm{Y}$ ) of 0.541 . This means that the relationship between individual consumer perceptions for Green Brand Knowledge (GBK) and Green Perceived Value (GPV) on Green Purchase Intention (GPI) is 0.326 and 0.541, respectively. The simultaneous relationship between Green Brand Knowledge (GBK) and Green Perceived Value (GPV) on Green Purchase Intention (GPI) is $0.81 \%$.

\section{CONCLUSION}

There is a significant relationship between Green Brand Knowledge (GBK) and Green Purchase Intention (GPI) partially, so that changes that occur in Green Brand Knowledge (GBK) will cause significant changes in Green Purchase Intention (GPI), if Green Perceived Value (GPV) has not changed. Likewise, the relationship between Green Perceived Value (GPV) and Green Purchase Intention (GPI) shows significant, so that changes that occur in Green Perceived Value (GPV) will cause significant changes in Green Purchase Intention (GPI), if Green Brand Knowledge (GBK) has not changed.

Green Brand Knowledge (GBK) and Green Perceived Value (GPV) with Green Purchase Intention (GPI) simultaneously have a very strong and significant relationship. Therefore, if there is a change in the two variables of Green Brand Knowledge (GBK) and Green Perceived Value (GPV) together, it will cause significant changes to Green Purchase Intention (GPI).

The findings also show that Green Brand Knowledge (GBK) and Green Perceived Value (GPV) have a positive impact on Green Purchase Intention (GPI), implying that green consumer knowledge is another successful strategy for facilitating the development of green brand knowledge by strengthening the connection between green perceived value and green purchase intention.

\section{Recommendations \& Limitations}

From this research, the authors provide the following suggestions:

1. It is necessary to improve the dimensions of Green Brand Awareness to improve Green Brand Knowledge (GBK) so that the memory associated with various associations related to environmental commitment and environmental awareness increases.

2. Necessary improvements in the customer dimension and Environmental Benefit for concern to improve Green Perceived Value (GPV), so that consumers receive a thorough assessment on the entire benefit and something that is sacrificed is based on the desire of the environment, with the hope there will be sustainability and improvements to the green needs. 
Even though the current research makes many analytical contributions and has managerial ramifications, it is not without flaws. To begin, this research relies on the tabulation of data obtained from the results of administering questionnaires, with the data being used to test the hypothesis. As a result, collecting longitudinal data will help researchers better understand this complex relationship. Second, since this research looks at the model using data from Bandung-Indonesia, the generalizability of our findings is restricted. A comparative study could be conducted in the future to better understand the role of cultural differences in the growth of customers' eco-friendly brand knowledge.

\section{REFERENCES}

Chang, C. H. (2011). The influence of corporate environmental ethics on competitive advantage: The mediation role of green innovation. Journal of Business Ethics, 104, 361-370.

Chen, \& Chang. (2012). Echance Green Purchase Intentions: The Roles of Green Perceived Value, Green Perceived Risk, and Green Trust. Management Decision.

Chen, Y. S. (2013). Towards green loyalty: Driving from green perceived value, green satisfaction, and green trust. Sustainable Development, 21, 294-308.

Dehghanan, H., \& Bakhshandeh, G. (2014). The Impact of Green Perceived Value and Green Perceived Risk on Green Purchase Behavior of Iranian Consumers. International Journal of Management and Humanity Sciences, 3 (2), 1349-1357.

Easily Dissolve in Hot Water (2020). www.cassaplast.co.id. accessed 10/10/20.

Huang, Y. C., Yang, M. \& Wang, Y. C. (2014). Effects of green brand on green purchase intention. Marketing Intelligence and Planning, 32(3), 250-268.

Indrawati. (2015). Metode Penelitian Manajemen Dan Bisnis: Konvergensi Teknologi Komunikasi Dan Informasi. Rafika Aditama.

Juwaheer, T. D., Pudaruth, S. \& Noyaux, M. M. E. (2012). Analysing the impact of green marketing strategies on consumer purchasing patterns in Mauritius. World Journal of Entrepreneurship, Management and Sustainable Development, 8(1), 36-59.

Kumar, P. dan B.M Ghodeswar. (2015). "Factors Affecting Consumers' Green Product Purchase Decisions. Marketing Intelligence \& Planning. Vol. 33, No. 3, pp. 330-347. https://doi.org/10.1108/MIP-032014-0068.

Kusuma, Pratiwi Ni Putu Deviary, Sulhaini, and Rinuasturi Baiq Handayani. 2018. The Effect of Environmental Knowledge, Green Advertising and Environmental Attitude toward Green Purchase Intention. RJOAS, vol. 6, no. 78, page. 95-105.

Lin, J., Lobo, A., \& Leckie, C. (2017). The role of benefits and transparency in shaping consumers' green perceived value, self-brand connection and brand loyalty. Journal of Retailing and Consumer Services, 35, 133-141.

Lin,J.and Zhou, Z.(2020), "The positioning of green brands in enhancing their image: the mediating roles of green brand innovativeness and green perceived value", International Journal of Emerging Markets, Vol. ahead-of-print No. ahead-of-print. https://doi.org/10.1108/IJOEM-06-20200657.

Masalah Sampah Plastik di Indonesia dan Dunia (2017). www.lingkunganhidup.co. accessed 12/12/20.

Mohd Suki, N. Green product purchase intention, (2016): Impact of green brands, attitude, and knowledge. Br. Food J. 2016, 118, 2893-2910.

Ottman, Jacquelyn A. 2011. The New Rules of Green Marketing Strategies, Tools, and Inspiration for Sustainable Branding. UK: Greenleaf Publishing.

Purningsih, Dewi. (2018). Sampah Sedotan Plastik Peringkat ke-5 Penyumbang Sampah Plastik di Dunia. www.greeners.co. accessed 11/15/20.

R. Yusiana and A. Widodo, (2016), The Influence of Green Marketing on Perceived Value of Pertamax Purchasing Decision, Proceedings of the 2016 Global Conference on Business, Management and Entrepreneurship, https://doi.org/10.2991/gcbme-16.2016.33

Riduwan, dan Engkos Achmad Kuncoro. 2017. Cara Menggunakan dan Memakai Path Analysis (Analisis Jalur). Bandung: Alfabeta.

Tekade, A. B., \& Sastikar, S. S. (2015). Present Green Marketing: Importance and challenges in Customer satisfaction. International Journal for Administration in Management, Commerce and Economics, 3, 308 - 312.

Shaharudin, Pani, Mansor, \& Elias. (2010). Factors Affecting Pur-Chase Intention of Organic Food in MalaySia's Kedah State. 105.

Sugiyono. (2019). Metode Penelitian Kuantitatif, Kualitatif Dan R\&D. Bandung: Alfabeta. 
Suki. (2016). Green Product Purchase Intention: Impact of Green Brands, Attitude, And Knowledge. Emerald Group Publishing.

Syahrianto, Muhammad. (2019). Furec Ramah Lingkungan dan Bisa Didaur Ulang Jadi Produk Rumah Tangga. www.wartaekonomi.co.id.

Verma, V.K.; Chandra, B.; Kumar, S., (2019), Values and ascribed responsibility to predict consumers' attitude and concern towards green hotel visit intention. J. Bus. Res. 2019, 96, 206-216

Yang, \& Peterson. (2014). Customer Perceived Value, Satisfaction, And Loyalty: The Role of Switching Costs. 12.

Zhao, H.-h., Gao, Q., Wu, Y.-p., Wang, Y., \& Zhu, X.-d. (2014). What affects green consumer behavior in China? A case study from Qingdao. Journal of Cleaner Production, 63, 143- 151. 